\title{
The Use of Herbicide Safener Increases the Selectivity of Nicosulfuron to Maize Crops
}

\author{
Rafaela Cinelli, Andrei Sauthier Barbieri \\ Federal Institute of Rio Grande do Sul-IFRS, Campus Sertão, Brazil
}

Rubens Antonio Polito, Tamara Heck

Federal University of Pelotas-UFPel, Brazil

Noryam Bervian Bispo, Anderson Luis Nunes

Federal Institute of Rio Grande do Sul-IFRS, Campus Sertão, Brazil

Received: Aug. 5, 2020

doi:10.5296/jas.v8i4.17487
Accepted: Sep. 24, $2020 \quad$ Published: Sep. 29, 2020

URL: https://doi.org/10.5296/jas.v8i4.17487

\begin{abstract}
The herbicide nicosulfuron is an important tool for weed control in maize crops; however, its incorrect use can cause yield losses to crops due to its high toxicity. The objective of this work was to evaluate the efficiency of using herbicide safener to increase selectivity of nicosulfuron to maize crops. The experiment was conducted in field conditions, and the treatments consisted of dose-response curves, using nicosulfuron at rates of $0,15,30,45$, and $60 \mathrm{~g}$ ha-1, applied with safener and/or malathion to maize crops at the V5-V6 stage. The use of organophosphorus insecticides such as malathion decrease the selectivity of nicosulfuron to maize crops. Rates of up to $60 \mathrm{~g}$ ha- 1 were selective to the maize crops when using nicosulfuron or nicosulfuron + safener. However, plant height decreased 0.19 and $0.91 \mathrm{~cm}$ for each gram of nicosulfuron in the treatments nicosulfuron + safener + malathion, and nicosulfuron + malathion, respectively, at 28 days after the application. The phytotoxicity increased $0.19 \%$ and $0.97 \%$ in the treatments nicosulfuron + safener + malathion and nicosulfuron + malathion, respectively. The number of grains per row and grain yield were affected by the treatments with nicosulfuron + malathion, presenting decreases of 0.09 grains
\end{abstract}


and $52 \mathrm{~kg}$ ha-1, respectively. Thus, adding safener to the herbicide mixture increases the selectivity of nicosulfuron to maize crops, decreases damages regarding plant height and phytotoxicity, and prevents effects of the herbicide on the number of grains per row and grain yield, up to the rate of $60 \mathrm{~g}$ ha- 1 .

Keywords: phytotoxicity, protector, Zea mays L.

\section{Introduction}

Maize (Zea mays L.) is the main energy ingredient in animal diets, mainly for non-ruminants; $70 \%$ to $80 \%$ of the maize produced is intended to feed production for animal protein production (Alves et al., 2015). The planted area with maize in the summer crop season 2018/2019 in Brazil reached 4,966,700 hectares, with enough production to meet the domestic demand, and an expected increase of $6.4 \%$ in planted area for the winter crop season of 2018/19 (CONAB, 2019).

Maize is very sensitive to competition with weeds, because a high weed population limits resources, negatively affecting agricultural crops (Ghanizadeh et al., 2014). Weeds can cause grain yield losses of up to $65 \%$, depending on the infestation duration (Gantoli et al., 2013); thus, weed management is essential to obtain satisfactory yields.

Herbicide and insecticide can be applied simultaneously in post-emergence, which made this tank mixture practice frequent due to the lower application cost; however, mixtures of nicosulfuron with organophosphorus insecticides, such as malathion, can reduce the herbicide selectivity to crops, causing yield losses (Maciel et al., 2018). Organophosphorus insecticides reduce the maize tolerance to herbicides of the sulfonylurea group by inhibiting cytochrome P450 monooxygenase enzymes (Kreuz \& Fronn-Pfister, 1992). This enzyme complex is abundant in maize plants and is responsible for metabolization and detoxification of chemical toxic compounds (Skipsey et al., 2011), such as the herbicide nicosulfuron (Nelson \& Werck-Reichhart, 2011; Liu et al., 2019).

A formulation of nicosulfuron combined with a safener of undisclosed name was recently launched in Brazil to ensure the selectivity of nicosulfuron to maize crops. Safeners are chemical compounds that increase the metabolization of herbicides of plants by inducing the expression of detox genes such as the Cyp P450 (Riechers et al., 2010; Kraehmer et al., 2014; Elmore et al., 2015). The safener naphthalic anhydride has shown decreases in damages caused by nicosulfuron in mixtures with the organophosphorus insecticide terbufos in maize crops (Siminszky et al., 1995). Moreover, the compound BAS-145138 decreased injuries caused by nicosulfuron in a sensitive sweet maize cultivar (Robinson et al., 1996). In this context, the objective of this work was to evaluate the efficiency of using herbicide safener to increase selectivity of nicosulfuron to maize crops.

\section{Method}

\subsection{Experiment Site}

The experiment was conducted in field condition in the municipality of Ibiraiaras, RS, Brazil $\left(28^{\circ} 26^{\prime} 49^{\prime \prime} \mathrm{S}, 51^{\circ} 37^{\prime} 50^{\prime \prime} \mathrm{W}\right.$, and altitude of $\left.768 \mathrm{~m}\right)$ from October 2018 to April 2019. The 
climate of the region is Cfa, according to the Köppen classification. The soil of the area was classified as Typic Hapludox (Latossolo Vermelho Distroferrico humico) (STRECK et al., 2018).

\subsection{Treatments and Experimental Design}

The experiment was conducted in a randomized block design with four replications; the treatments consisted of dose-response curves, using nicosulfuron at rates of $0,15,30,45$, and $60 \mathrm{~g}$ ha-1, applied with safener and/or malathion to maize crops at the V5-V6 stage. The malathion rate used in the curves was of $1,000 \mathrm{ml}$ ha- 1 for all nicosulfuron rates. The recommended rate of nicosulfuron for weed control in maize crops is $60 \mathrm{~g}$ ha-1 (ADAPAR, 2019). The experimental units consisted of four 5-meter rows spaced $0.8 \mathrm{~m}$ apart (area of 16 $\left.\mathrm{m}^{2}\right)$.

\subsection{Experiment Details}

The experiment was conducted in a no-till system area with black oat plants, used for grazing in the winter. These plants were desiccated at 14 days before the maize planting, using glyphosate (720 g a.e. ha-1), clethodim (108 g ha-1), and amicarbazone (280 g ha-1). Seeds of the maize hybrid JM-4M50 (Jmen Sementes), which present tolerance to nicosulfuron herbicide, were sowed on October 20, 2018 with spacing of $0.8 \mathrm{~m}$ between rows, using 4.8 seeds per linear meter. Soil fertilization at sowing consisted of applying $300 \mathrm{~kg}$ ha- 1 of the 8-20-20 (N-P-K) formulation. Topdressing was carried out when the maize was at the vegetative stage (V7), using $250 \mathrm{~kg}$ ha-1 of urea (112.5 $\mathrm{kg}$ of $\mathrm{N}$ ha-1). Weeds were controlled during the experiment by weekly hoeing.

The treatments were applied when the maize plants were at the V5-V6 stage, using a CO2-pressurized sprayer and a solution volume of $180 \mathrm{~L}$ ha-1. The spray boom had four flat jet nozzles (Micron Air 11002) spaced $0.5 \mathrm{~m}$ apart.

\subsection{Data Collect}

Plant height and phytotoxicity were evaluated at 7, 14, 21, and 28 days after application (DAA) of the treatments. Plant height was measured in three linear meters of plants in the center of each plot, from the ground up to the insertion of the last leaf. Phytotoxicity was evaluated visually based on a percentage scale, in which $0 \%$ represents the absence of symptoms and $100 \%$ represents the death of the plant.

The maize grains of plants in two linear meters of the two central rows of each plot $\left(3.2 \mathrm{~m}^{2}\right)$ were harvested manually on April 12, 2019. The number of grains per row and 1,000-grain weight were evaluated. The number of grains per row was counted in 5 ears per plot; the ears were threshed and the grains were weighed to evaluated grain yield, which was expressed in $\mathrm{kg}$ ha-1; the moisture of the grains was corrected to $13 \%$.

\subsection{Statistical Analysis}

The data were subjected to regression analyses using the SigmaPlot 12.5 program, establishing a linear correlation between the variables analyzed and herbicide rates used. 


\section{Macrothink}

\section{Results and Discussion}

Considering that the same nicosulfuron rates were used for all dose-response curves, all differences between treatments are assumed to be due to the presence or absence of safener and/or insecticide malathion.

The dose-response curves of nicosulfuron and nicosulfuron + safener were not significant for plant height, phytotoxicity, number of grains per row, and grain yield, with no expressive variations for the rates used when compared to the rate zero (Figure 1A, 1B, 1C, 1D, 2A, and 2B). This was expected, since the hybrid used is tolerant to nicosulfuron and the rates used are within the recommended rates. Maciel et al (2018) treated maize plants of the hybrid 2B-710 with nicosulfuron applied single at the V6 stage and found low toxicity levels, reaching 5\% and $3 \%$ at 7 and 14 DAA, respectively, and no effect on plant height in relation to the control. Tolerant hybrids are little damaged by nicosulfuron; these plants have the cytochrome P450 monooxygenase enzyme that detox nicosulfuron molecules (Powles \& Yu, 2010; Nadula et al., 2018; Ye et al., 2019). The herbicide nicosulfuron belong to the sulfonylurea group, which is among the groups that present sensitivity to the action of cytochrome P450 (Carvalho et al, 2009).

However, this effect is not maintained when adding organophosphorus insecticides to the applied solution. The dose-response curve of nicosulfuron + malathion showed that the plant height decreased 0.62 and $0.91 \mathrm{~cm}$ at 21 and 28 DAA, respectively, for each gram of nicosulfuron (Figure 1A and 1B). The same result was found for phytotoxicity; each gram of nicosulfuron increased phytotoxicity in $1.0 \%$ and $0.97 \%$ at 21 and 28 DAA, respectively (Figure 1C and 1D). 

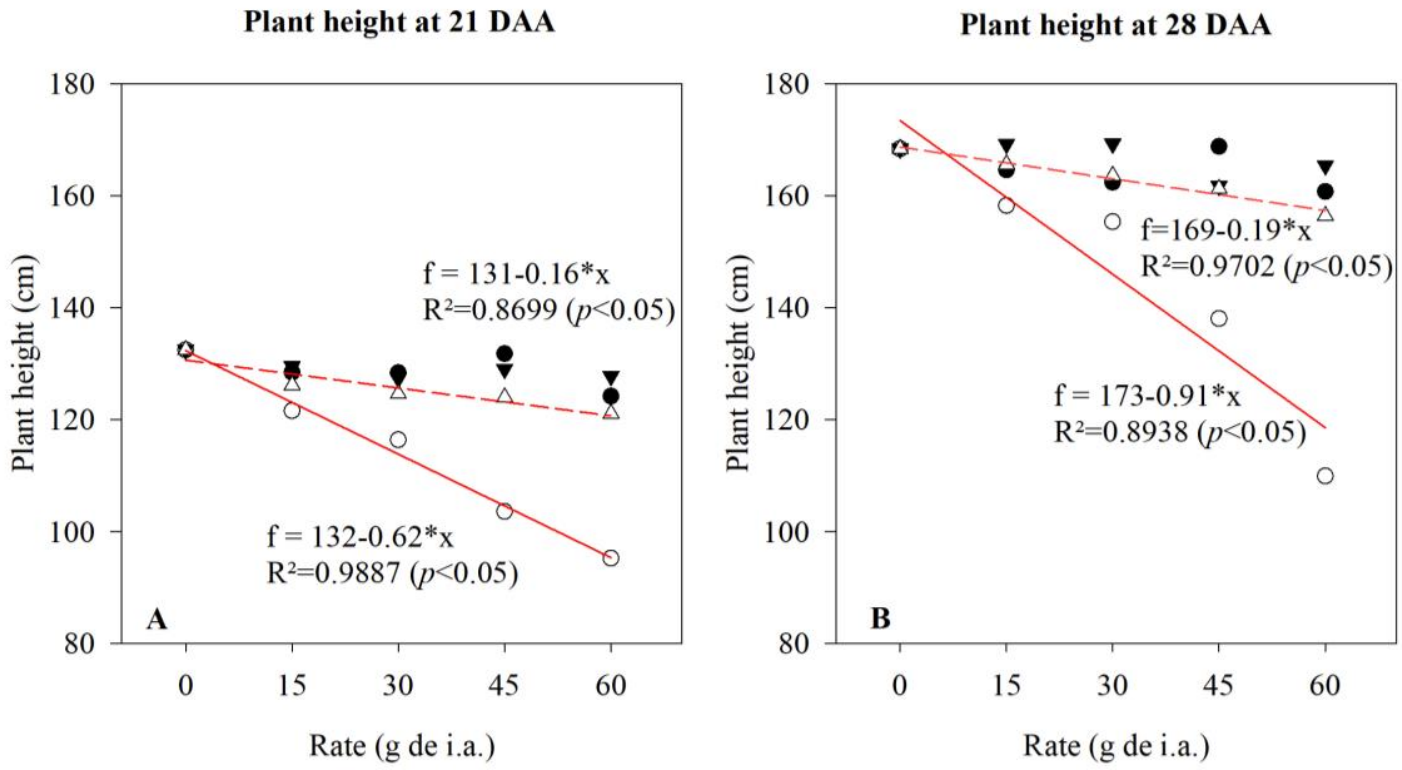

Phytotoxicity at 21 DAA

Phytotoxicity at 28 DAA
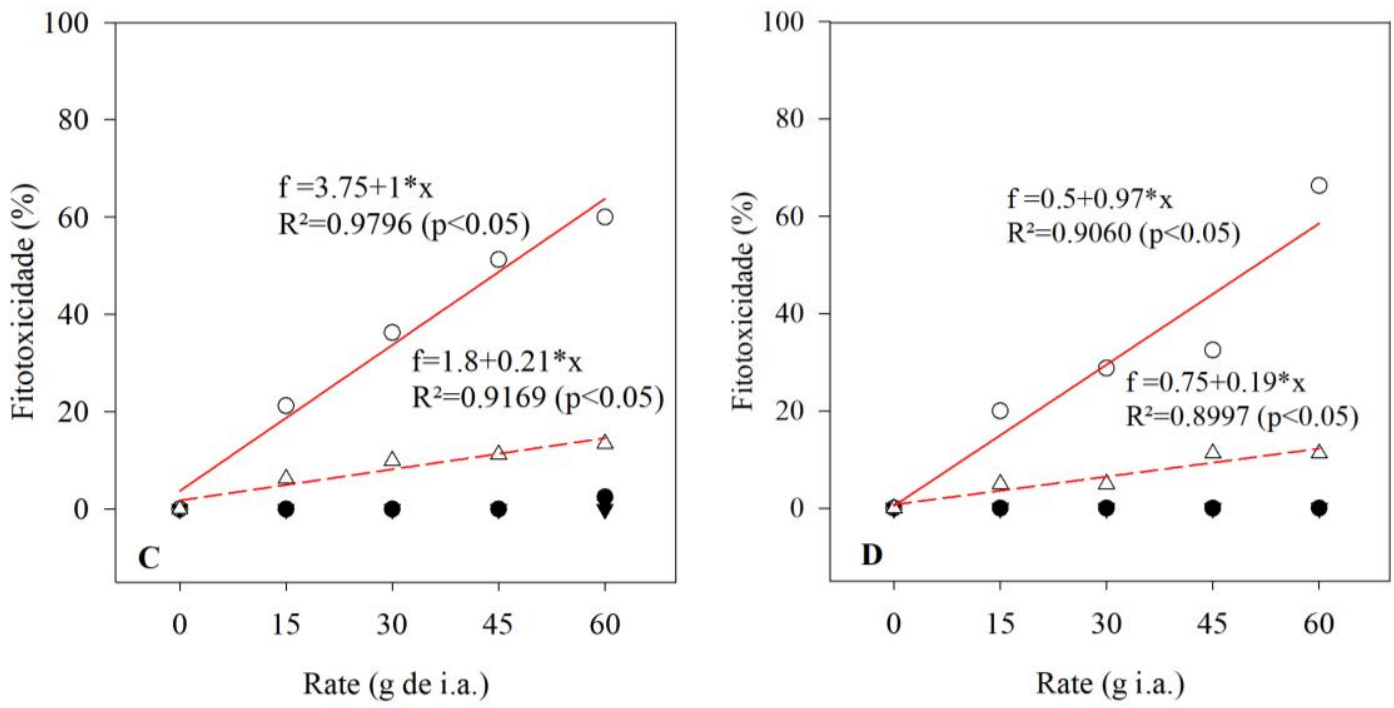

- Nicossulfuron

- Nicossulfuron+Malation

v Nicossulfuron+Safener

$\triangle \quad$ Nicossulfuron+Safener+Malation

-- Nicossulfuron+Safener+Malation

Nicossulfuron+Malation

Figure 1. Plant height and phytotoxicity in maize plants as a function of nicosulfuron rates combined with safener and/or malathion, at 21 and 28 days after application (DAA).

Ibiraiaras, RS, Brazil, 2019

The CYP P450 activity is suppressed when malathion is added to the applied solution, making a tolerant cultivar, susceptible to the herbicide (Paporisch \& Rubin, 2017). The maize hybrid 2B-710 treated with nicosulfuron combined with the organophosphorus insecticide chlorpyrifos presented $24.4 \%$ higher phytotoxicity and $37 \%$ lower plant height at 14 DAA 
when compared to plants treated only with nicosulfuron (Maciel et al, 2018).

The treatment nicosulfuron + safener + malathion showed less expressive decreases in plant height than the treatment nicosulfuron + malathion. The plant height decreased $0.16 \mathrm{~cm}$ at per gram of nicosulfuron added, at 21 DAA (Figure 1A), reaching $0.19 \mathrm{~cm}$ at 28 DAA (Figure 1B). Phytotoxicity, increased $0.21 \%$ and $0.19 \%$ at 21 and 28 DAA, respectively (Figure 1C and 1D). The biomass yield of sweet maize plants of tolerant lines and hybrids treated with malathion followed by foramsulfuron decreased $35 \%$ and 50\%, respectively; whereas plants treated with malathion followed by foramsulfuron + safener (isoxadifen) showed no decreases in biomass yield (Paporisch \& Rubin, 2017). The application of nicosulfuron + malathion inhibited the growth of sweet maize plants in 57\%; however, when including safener (isoxadifen) in the application, the decrease in plant growth was 20\% (Sun et al, 2017). The safener added to the solution induces the expression of genes that codify cytochrome P450 monooxygenase enzymes (Riechers et al, 2010), which metabolize the herbicide transforming it into metabolites without herbicide action (Duhoux et al, 2017).

The dose-response curve of nicosulfuron + safener + malathion was not significant for number of grains per row and grain yield (Figure 2A and 2B). The dose-response of nicosulfuron + malathion decreased grain yield in $52 \mathrm{~kg}$, and grains per row in 0.09 per gram of nicosulfuron per hectare added (Figure 2A and 2B). The 1,000-grain weights of all treatments were similar (data not presented). The nicosulfuron rates of up to $40 \mathrm{~g}$ ha- 1 had no effect on grain yield of a tolerant maize hybrid (Pioneer P30F80); however, the yield was 7,333 and $4,957 \mathrm{~kg}$ ha-1 for the rates of 10 and $40 \mathrm{~g}$ ha-1, respectively, when the organophosphorus insecticide chlorpyrifos was added (Silva et al., 2005).
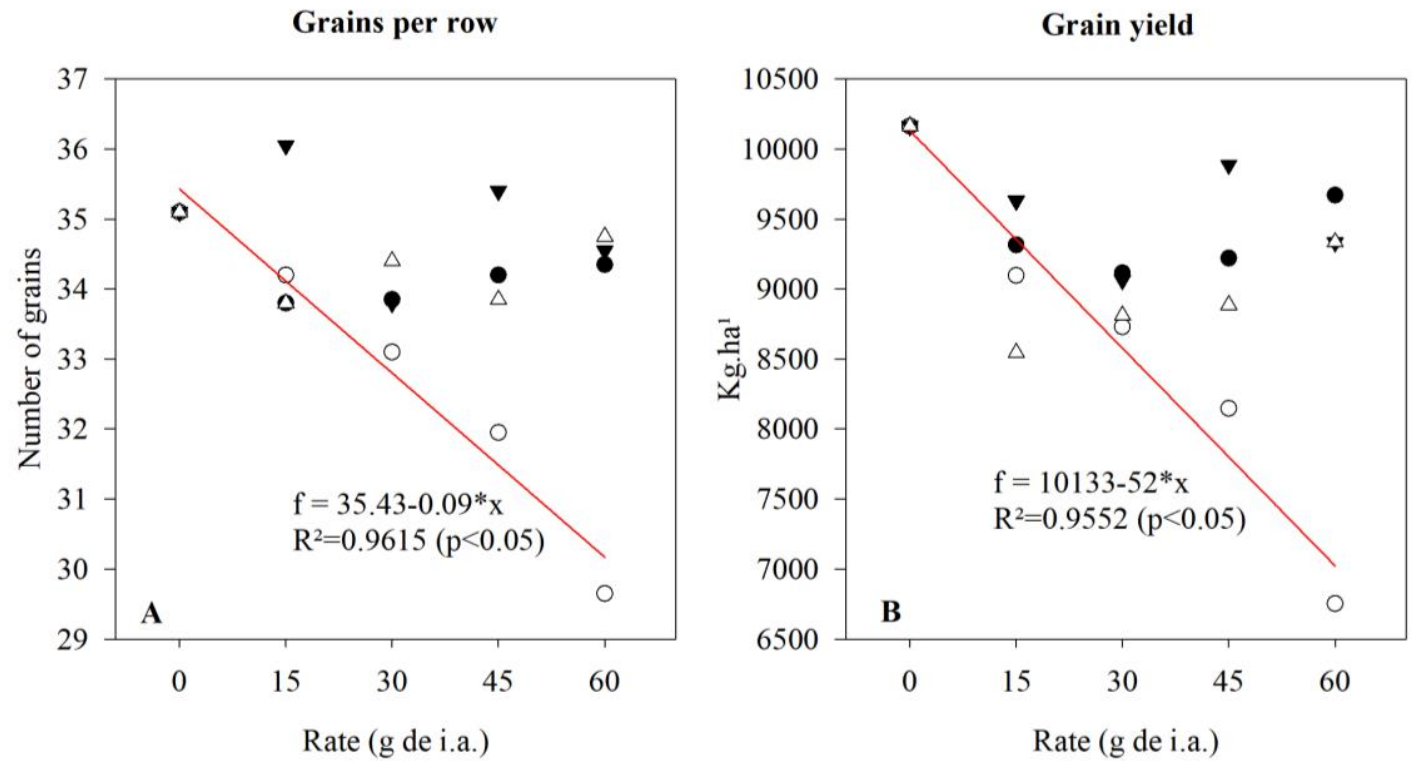

- Nicossulfuron

- Nicossulfuron+Malation

v Nicossulfuron+Safener

$\triangle$ Nicossulfuron+Safener+Malation

Nicossulfuron+Malation 
Figure 2. Number of grains per row (A) and grain yield (B) of maize as a function of nicosulfuron rates combined with safener and/or malathion. Ibiraiaras, RS, Brazil, 2019

The addition of safener in the formulated mixture (nicosulfuron + safener) increased the selectivity of nicosulfuron to maize crops and was an important tool for the use of nicosulfuron in cases of application of inappropriate rates, superposition of deposition during application, application before the limit of seven days after the application of nitrogen soil fertilizers and organophosphorus insecticides, and when using hybrids with low tolerance to the herbicide.

\section{Conclusion}

The addition of safener to the formulated mixture (nicosulfuron + safener) increased the selectivity of nicosulfuron to maize crops. When not adequately applied, each gram of nicosulfuron applied per hectare of maize crop increases the toxicity by approximately $1 \%$ and reduces the grain yield by $52 \mathrm{~kg}$ ha- 1 .

\section{References}

ADAPAR. Agência de Defesa Agropecuária do Paraná. [Online] Available: http://www.adapar.pr.gov.br/modules/conteudo/conteudo.php?conteudo=389 (Jun 10, 2019).

Alves, B. M., Cargnelutti Filho, A., Burin, C., Toebe, C. B. M., \& Silva, L. P. (2015). Divergência genética de milho transgênico em relação à produtividade de grãos e da qualidade nutricional. Ciência Rural, 454 45), https://doi.org/10.1590/0103-8478cr20140471

Carvalho, S. J. P., Nicolai, M., Ferreira, R. R., Figueira, A. V. O., \& Christoffoleti, P. J. (2009). Herbicide selectivity by differential metabolism: considerations for reducing crop damages. Scientia Agricola, 6(1), 136-142. https://doi.org/10.1590/S0103-90162009000100020

CONAB. Acompanhamento da safra brasileira: grãos. [Online] Available: https://www.conab.gov.br/info-agro/safras/graos/boletim-da-safra-de-graos. (May 10, 2019).

Dohoux, A., Pernin, F., Desserre, D., \& Délye, C. (2017). Herbicide Safeners Decrease Sensitivity to Herbicides Inhibiting Acetolactate-Synthase and Likely Activate Non-Target-Site-Based Resistance Pathways in the Major Grass Weed Lolium sp. (Rye-Grass). Frontiers in Plant Science, 8, 1-14. https://doi.org/10.3389/fpls.2017.01310

Elmore, M. T., Brosnan, J. T., Armel, G. R., Vargas, J. J., \& Breeden, G. K. (2015). Influence of Herbicide Safeners on Creeping Bentgrass (Agrostis stolonifera) Tolerance to Herbicides. Weed Technol, 29(3), 550-560. https://doi.org/10.1614/WT-D-14-00045.1

Gantoli, G., Ayala, V. R., \& Gerhars, R. (2013). Determination of the critical period for weed control in corn. Weed Technol, 27(1), 63-71. https://doi.org/10.1614/WT-D-12-00059.1

Ghanizadeh, H., Lorzadeh, S., \& Aryannia, N. (2014). Effect of weed interference on Zea mays: growth analysis. Weed Biology and Management, 14(2), 133-137. https://doi.org/10.1111/wbm.12041 
Kraehmer, H., Laber, B., Rosinger, C., \& Schulz, A. (2014). Herbicides as Weed Control Agents: State of the Art: I. Weed Control Research and Safener Technology: The Path to $\begin{array}{lllll}\text { Modern } & \text { Agriculture. Plant } & \text { Physiology, 166, }\end{array}$ https://doi.org/10.1104/pp.114.241901

Kreuz, K., \& Fonn-Pfister, R. (1992). Herbicide-insecticide interaction in maize: malathion inhibits cytochrome P450-dependent primisulfuron metabolism. Pesticide Biochemistry and Physiology, 43(3), 232-240. https://doi.org/10.1016/0048-3575(92)90036-Y

Liu, X., Bi, B., Li, B., Tian, S., Wang, J., Zhang, H., ... McElroy, J.S. (2019). Rapid identification of a candidate nicosulfuron sensitivity gene (Nss) in maize (Zea mays L.) via combining bulked segregant analysis and RNA-seq. Theoretical and Applied Genetics, 132, 1351-1361. https://doi.org/10.1007/s00122-019-03282-8

Maciel, C. D. G., Silva, A. A. P., Helvig, E. O., Neto, A. M. O., Guerra, N., Sola Jr, L. C., \& Karam, D. (2018). Seletividade de misturas de herbicidas e inseticidas em tanque aplicadas em híbridos de milho. Revista Brasileira do Milho e Sorgo, 17(2), 287-302. https://doi.org/10.18512/1980-6477/rbms.v17n2p287-302

Nadula, V. K., Riechers, D. E., Ferhatoglu, Y., Barrett, M., Duke, S. O., Dayan, F. E., ... Ma, R. (2018). Herbicide Metabolism: Crop Selectivity, Bioactivation, Weed Resistance, and Regulation. Weed Science, 67(2), 149-175. https://doi.org/10.1017/wsc.2018.88

Nelson, D., \& Werck-Reichhart, D. (2011). A P450 centric view of plant evolution. Plant Journal 66(1), 194-211. https://doi.org/10.1111/j.1365-313X.2011.04529.X

Paporisch, A., \& Rubin, B. (2017). Isoxadifen safening mechanismin sweet corn genotypeswith differential response to P450-metabolized herbicides. Pesticide Biochemistry and Physiology, 138, 22-28. https://doi.org/10.1016/j.pestbp.2017.02.002

Powles, S. B., \& Yu, Q. (2010). Evolution in Action: Plants Resistant to Herbicides. Plant Biology, 61, 317-347. https://doi.org/10.1146/annurev-arplant-042809-112119

Riechers, D. E., Kreuz, K., \& Zhang, Q. (2010). Detoxification without Intoxication: Herbicide Safeners Activate Plant Defense Gene Expression. Plant Physiology, 153, 3-13. https://doi.org/10.1104/pp.110.153601

Robinson, D. K., Monks, D. W., \& Burton, J. D. (1996). Safening Influence of LAB 145138 on Nicosulfuron, Terbufos and Bentazon Interactions in Sweet Corn (Zea mays). Weed Science, 44(2), 339-44. https://doi.org/10.1017/S0043174500093978

Silva, A. A., Freitas, F. M., Ferreira, L. R., \& Jakelaitis, A. (2005). Efeito de mistura de herbicida com inseticida sobre a cultura do milho, as plantas daninhas e a lagarta-do-cartucho. Planta Daninha, 23(3), 517-525. https://doi.org/10.1590/S0100-83582005000300016

Siminszky, B., Corbin, F. T., \& Sheldon, Y. (1995). Nicosulfuron Resistance and Metabolism in Terbufos and Naphthalic Anhydride-Treated Corn. Weed Science, 43(2), 163-8. https://doi.org/10.1017/S0043174500081005 


\section{Macrothink}

Journal of Agricultural Studies

ISSN 2166-0379 2020, Vol. 8, No. 4

Skipsey, M., Knight, K. M., Brazier-Hicks, M., Dixon, D.P., Steel, P. G., \& Edwards, R. (2011). Xenobiotic Responsiveness of Arabidopsis thaliana to a Chemical Series Derived from a Herbicide Safener. Journal of Biological Chemistry, 286(37), 32268-32276. https://doi.org/10.1074/jbc.M111.252726

Streck, E. V., Flores, C. A., \& Schneider, P. (2018). Solos do Rio Grande do Sul. (3rd ed.). Emater/RS-Ascar, Brasil. p. 166-1667.

Sun, L., Wu, R., Su, W., Gao, Z., \& Lu, C. (2017). Physiological basis for isoxadifen-ethyl induction of nicosulfuron detoxification in maize. PLOS ONE, 12(3), 1-16. https://doi.org/10.1371/journal.pone.0173502

Ye, F., Zhai, Y., Kang, T., Wu, S., Li, J., Gao, S., .. Fu, Y. (2019). Rational design, synthesis and structure-activity relationship of novel substituted oxazole isoxazole carboxamides as herbicide safener. Pesticide Biochemistry and Physiology, 157, 60-68. https://doi.org/10.1016/j.pestbp.2019.03.003

\section{Copyright Disclaimer}

Copyright for this article is retained by the author(s), with first publication rights granted to the journal.

This is an open-access article distributed under the terms and conditions of the Creative Commons Attribution license (http://creativecommons.org/licenses/by/4.0/). 